\title{
Influence of different riparian vegetation widths and substrate types on the communities of larval Odonata (Insecta) in southern Brazilian streams
}

Influência de diferentes larguras da vegetação ripária e tipos de substrato sobre a estrutura de comunidade de larvas de Odonata (Insecta) em riachos do sul do Brasil

Mateus Marques Pires ${ }^{1}$ (D), Nícolas Felipe Drumm Müller ${ }^{2}$ (D), Cristina Stenert ${ }^{1}$ (D) and Leonardo Maltchik ${ }^{1 *}$

${ }^{1}$ Laboratório de Ecologia e Conservação de Ecossistemas Aquáticos, Universidade do Vale do Rio dos Sinos - UNISINOS, Av. Unisinos, 950, CEP 93022-750, São Leopoldo, RS, Brasil

${ }^{2}$ Universidade Federal do Rio Grande do Sul - UFRGS, Av. Bento Gonçalves, 9500, CEP 91501-970, Porto Alegre, RS, Brasil

*e-mail: maltchik@unisinos.br

Cite as: Pires, M.M. et al. Influence of different riparian vegetation widths and substrate types on the communities of larval Odonata (Insecta) in southern Brazilian streams. Acta Limnologica Brasiliensia, 2020, vol. 32, e301.

Abstract: Aim: We assessed the influence of substrate type and categories of riparian vegetation widths on the community structure of Odonata (Insecta) in southern Brazilian streams. Methods: Sampling took place in twelve stream reaches differing in their riparian vegetation widths (from more than $40 \mathrm{~m}$ up to less than $5 \mathrm{~m}$ ). Larval odonates were collected in inorganic (stone and gravel) and organic (leaf litter) substrates at each stream reach. Differences in Odonata composition among substrates and categories of riparian vegetation width were tested using PERMANOVA and visualized with ordination diagrams. In addition, we assessed the influence of riparian vegetation width taking into account two levels of resolutions: fine (four categories: $>40 \mathrm{~m}, 30-15 \mathrm{~m}, 15-5 \mathrm{~m}$ and $<5 \mathrm{~m}$ ) and coarse (narrower and broader than $15 \mathrm{~m}$ ). Results: Odonata composition differed more strongly according to substrate type regardless of the level of resolution. Organic substrate (litter) had different composition and higher richness than inorganic ones. Odonata composition significantly differed between riparian vegetation widths at the coarser level of resolution (narrower and broader than $15 \mathrm{~m}$ ); at the coarser level, the interaction between substrate and riparian widths was significant, with the composition from litter substrate in broader widths differing from stone and gravel in narrower widths. Conclusions: The composition of odonate larvae responded to the major reductions in riparian widths (above $>15 \mathrm{~m}$ ), indicating that reductions above this level are enough to affect the community structure of Odonata. Additionally, the different composition of Odonata in organic substrates in broader riparian vegetation widths compared to inorganic substrates in narrower widths indicate a complex relationship between riparian vegetation and substrate in the assembly of insect communities in southern Brazilian forest streams. The interaction between riparian vegetation widths and substrate suggests that the effects of reductions in riparian widths on Odonata composition are not similar across substrate types.

Keywords: aquatic insects; substrate composition; community structure; macroinvertebrates; riparian zones. 
Resumo: Objetivo: Avaliamos a influência do tipo de substrato e categorias de larguras de vegetação ripária na estrutura da comunidade de Odonata (Insecta) em riachos do sul do Brasil. Métodos: A amostragem ocorreu em doze segmentos de riachos que diferiam em suas larguras de vegetação ripária (de mais de $40 \mathrm{~m}$ a menos de $5 \mathrm{~m}$ ). As larvas de Odonata foram coletadas em substratos inorgânicos (pedra e cascalho) e orgânicos (folhiço) em cada segmento. As diferenças na composiçáo de Odonata entre substratos e categorias de largura da vegetação ripária foram testadas usando PERMANOVA e visualizadas com diagramas de ordenação. Além disso, analisamos a influência da largura da vegetação ripária, levando em consideração dois níveis de resolução: mais fina (quatro categorias: $>40 \mathrm{~m}, 30-15 \mathrm{~m}$, $15-5 \mathrm{~m} \mathrm{e}<5 \mathrm{~m}$ ) e mais grossa (mais estreita e mais larga que $15 \mathrm{~m}$ ). Resultados: A composiçấo do Odonata diferiu mais fortemente de acordo com o tipo de substrato, independentemente do nível de resolução. O substrato folhiço apresentou composição diferente do que os inorgânicos. Foi detectado um efeito das larguras ripárias na composição de Odonata na escala grossa, enquanto na escala fina, a interação entre as larguras do substrato e ripária foi significativa, com a composição do substrato folhiço em larguras de vegetação maiores diferindo da composição pedra e do cascalho em larguras mais estreitas. Conclusóes: A composição das larvas de Odonata respondeu às maiores reduçóes nas larguras ripárias (acima de $15 \mathrm{~m}$ ), indicando que reduçôes acima desse nível são suficientes para afetar a estrutura da comunidade destes insetos. Além disso, a composição diferente de Odonata em substratos orgânicos em larguras de vegetação ripária mais amplas em comparação com substratos inorgânicos em larguras mais estreitas indica uma relaçáo complexa entre vegetação ripária e substrato na estruturação de comunidades de insetos em riachos no sul do Brasil. A interação entre as larguras da vegetação ripária e o substrato sugere que os efeitos das reduçóes nas larguras ripárias na composição de Odonata não são semelhantes entre os tipos de substrato.

Palavras-chave: insetos aquáticos; composição do substrato; estrutura de comunidade; macroinvertebrados; zonas ripárias.

\section{Introduction}

The integrity of the riparian vegetation is closely associated with stream biodiversity (Allan \& Castillo, 2007). Many studies report detrimental effects of reductions or removal of riparian vegetation on ecosystem functioning and the structure of aquatic and riparian communities in streams, including biodiversity losses, changes in species composition and reduced water quality (Kiffney et al., 2003; Death \& Collier, 2010; Lorion \& Kennedy, 2009; Iñiguez-Armijos et al., 2014; Dala-Corte et al., 2020). Ensuring adequate amounts of riparian vegetation cover thus became a crucial point for policies aiming at the maintenance of stream integrity (Marczak et al., 2010). Various studies attempted at estimating the widths of riparian vegetation required to minimize negative impacts on stream biodiversity (e.g., Kiffney et al., 2003; Marczak et al., 2010; Valle et al., 2013; Moraes et al., 2014; Braun et al., 2018). However, a range of responses to modification in riparian widths is reported for different aquatic communities across different ecosystems (Kiffney et al., 2003; Death \& Collier, 2010; Lorion \& Kennedy, 2009; IńiguezArmijos et al., 2014; Valle et al., 2013; Moraes et al., 2014). This scenario hinders consensus on the establishment of thresholds of riparian vegetation width for detection biodiversity loss (Leal et al., 2018).
The varying relationships between biodiversity and changes in riparian vegetation widths is not unsurprising as the ecological functioning of streams and riparian zones change with biome, climate and latitude (Tiegs et al., 2019). In addition, the composition of stream communities depends on processes operating at different spatial scales (e.g. catchment, riparian and instream) (Wang et al., 2003). Most studies assessed the role of riparian vegetation at different spatial extents (ranging from stream reach to catchment level) (Kiffney et al., 2003; Moraes et al., 2014; Iñiguez-Armijos et al., 2014), and thus their conclusions on the required vegetation widths to protect biodiversity are of limited application across study regions. In general, the importance of the processes structuring the composition of stream communities are contextdependent (Heino et al., 2015) and thus the thresholds of riparian vegetation likely also do (Dala-Corte et al., 2020).

At the riparian scale, modifications in the structure of the riparian vegetation alter light and temperature regimes; the input rate of allochthonous material (sediments and nutrients), food and microhabitat availability and eventually affect the stream metabolism and the associated biota (Sweeney et al., 2004; Rios \& Bailey, 2006; Dosskey et al., 2010). The role of riparian vegetation in structuring stream communities changes with several factors, including, catchment position and 
land use, and is assumedly of high importance in subtropical regions, where the input of material to streams is constant (Allan \& Castillo, 2007). For instance, Siegloch et al. (2017) demonstrated that even small changes in the complexity of the riparian vegetation (e.g. canopy coverage, tree and shrub sizes) elicited changes in aquatic insects in southern Brazilian streams. In addition, a previous study on the community structure of aquatic macroinvertebrates suggested that riparian buffer widths narrower than $15 \mathrm{~m}$ altered the macroinvertebrate community structure (Moraes et al., 2014). However, further studies identified slight variations in the responses of specific insect taxa (Viegas et al., 2014; Braun et al., 2018). Thus, the knowledge on how changes at the riparian scales, such as finer reductions in the width of the riparian vegetation, can affect stream communities in these Brazilian subtropical regions are so far inconclusive.

Investigating the effects of width of riparian vegetation on stream biodiversity is particularly important in Brazil, where over half of the extant native vegetation occurs within private properties (Soares-Filho et al., 2014). The new Brazilian Forest Code (Brasil, 2012) allowed reductions in riparian forests within private properties from 30 to $15 \mathrm{~m}$ (in special cases, less than $5 \mathrm{~m}$ ). Although the new code enforces landowners to conserve riparian vegetation, the minimal riparian width required should not vary according to stream width, rather to property size (Brasil, 2012), leading to great concern about the impacts on freshwater biota (Brancalion et al., 2016). Thus, studies that assess the impacts of changes in the widths of riparian forest buffer are fundamental in guiding public politics related stream conservation.

Aquatic insects are key components of the ecological dynamics of streams (Merritt et al., 2008). Particularly, insects of the order Odonata are closely associated with the conditions of the riparian vegetation (Corbet, 2004). Changes in riparian vegetation can affect the distribution of adults by loss of perches, change in heat exchange patterns and sunlight exposition (De Marco Júnior et al., 2015; Rodrigues et al., 2019). As for larvae, the effects of changes in riparian vegetation structure can occur via modification in the water quality or in-stream habitat structure (Luke et al., 2017; Mendes et al., 2019). Such characteristics of odonates make them useful tools for the assessment of the effects of changes in the structure of riparian vegetation (Samways \& Steytler, 1996). In fact, several studies detected responses of the community structure of
Odonata to modifications in the riparian vegetation, e.g., removal or reductions of forest cover and landuse conversion (Samways \& Steytler, 1996; FerreiraPeruquetti \& Fonseca-Gessner, 2002; Dutra \& De Marco Júnior, 2015; Rodrigues et al., 2016; Luke et al., 2017; Mendes et al., 2019). Although odonates have a long-lived aquatic stage (Corbet, 2004), there is increasing evidence for a high degree of congruent responses between larval and adult stages to environmental changes, including the amount of forest cover (Valente-Neto et al., 2016). It has thus recently suggested that a single life stage can be effectively used for biomonitoring purposes such as the assessment of disturbances in riparian vegetation (Valente-Neto et al., 2016; Mendes et al., 2017). The extent to which odonates are affected by reduction in riparian vegetation is, however, not well known (Luke et al., 2017). In tropical regions, some authors detected primary effects on Odonata composition rather than richness following the conversion of riparian vegetation, while others found effects in both metrics (Carvalho et al., 2013; Juen et al., 2014; Monteiro-Júnior et al., 2015; Luke et al., 2017; Calvão et al., 2018). This range of effects in Odonata community structure likely arises due to specific responses of the suborders Anisoptera and Zygoptera, which differ in ecophysiological traits (e.g., thermal conformance and body size; higher in the former suborder) and are differently affected by changes in riparian vegetation (De Marco Júnior et al., 2015).

However, few studies have assessed the effects of gradients of forest loss on Odonata distribution. The studies by Rodrigues et al. (2016, 2019) described nonlinear species-specific responses of Odonata to forest cover, thus suggesting that community-level responses to changes in riparian vegetation are complex and can be very difficult to predict. These nonlinear effects on Odonata distribution in response to changing forest cover possibly arise because additional and interacting ecological processes operating in riparian and in-stream habitats affect the occurrence of Odonata species (Corbet, 2004). For instance, the distribution of larval odonates is associated with in-stream environment variables, such as physicochemical conditions, flow rates and substrate type (Mendes et al., 2019). In particular, substrate type (organic or inorganic) can be a strong driver of the distribution of odonate larvae, because many genera show life habits that are distinctly favored in specific substrates (Carvalho \& Nessimian, 1998; Corbet, 2004). Earlier studies in subtropical 
streams showed that larvae from Zygoptera families (Calopterygidae, Coenagrionidae) prefer organic substrates (e.g., litter) due to their clinging ability, while some genera from Libellulidae (Brechmorhoga) and Gomphidae (Progomphus) are more associated with inorganic substrates (e.g. gravel, stones) because they can either burrow or sprawl across these microhabitats (Carvalho \& Nessimian, 1998; Assis et al., 2004; Pires et al., 2020). In addition, substrate type can be influenced by changes in riparian vegetation through modification in the input amount of sediment and allochthonous matter, which affect the in-stream environment, and, consequently, the aquatic insect community (Shilla \& Shilla, 2012; Mendes et al., 2019, 2020). Thus, the observed relative importance of riparian vegetation on Odonata distribution can change according to many site-level contingencies within a catchment and sometimes be overcame by local-level conditions associated with substrate (Roy et al., 2003; Buss et al., 2004; Ligeiro et al., 2013; Moraes et al., 2014; Braun et al., 2018).

In this study, we assessed the responses of larval odonate communities to changes in the width of the riparian vegetation and substrate type in subtropical Atlantic Forest streams in Southern Brazil. Assuming that the structure of the riparian vegetation affects the occurrence of species of Odonata, we hypothesized that increasing reductions in riparian vegetation width would lead to significant shifts in Odonata composition, and that larval stages of the order can be effective indicators of such changes. We expected predominance of Anisoptera taxa in narrower riparian vegetation widths because they are assumedly more tolerant to enhanced heat exchange and exposure to sunlight (i.e., conditions associated with absence or scarce riparian vegetation). In turn, Zygoptera taxa would be more associated with wider widths, because higher levels of shading assumedly favor the occurrence of thermal conformers such as the members of this suborder. In addition to the responses to the gradient of riparian vegetation width, we also expected to find changes in community composition according to substrate type, with genera with less mobile life habits more associated with organic (e.g., litter) substrates, while genera with burrowing or more mobile habits, with inorganic substrate (e.g., stones and gravel).

\section{Material and Methods}

\subsection{Study area}

The study area is located in the Sinos River (Rio dos Sinos) watershed, eastern region of the state of Rio Grande do Sul (southernmost Brazil; coordinates ranging from $29^{\circ} 20^{\prime}-30^{\circ} 10^{\prime} \mathrm{S}$; $50^{\circ} 15^{\prime}-51^{\circ} 20^{\prime} \mathrm{W}$; Figure 1). The Sinos River watershed covers 32 cities across an area of $-4000 \mathrm{Km}^{2}$ (total extension of $-190 \mathrm{~km}$ ) and its headwaters are located in the Southern Brazilian Plateau, at altitudes of $-900 \mathrm{~m}$ (UNISINOS, 2011). The climate in the Sinos River watershed is humid subtropical with annual average temperatures of $-20{ }^{\circ} \mathrm{C}$ and rainfall ranging from 1200 to $1500 \mathrm{~mm}$, without a dry season (Ibge, 1986). The original vegetation in the watershed consists of seasonal semi-deciduous forests covering the southern boundaries of the Atlantic Forest (Cordeiro \& Hasenack, 2009; IBGE, 2012).

Three medium-order (one 4th order and two 5th-order) and hydrologically permanent tributaries of the Sinos River, located at similar altitudes (ranging from $\sim 70 \mathrm{~m}$ to $\sim 140 \mathrm{~m}$ ), were selected for sampling. The selected tributaries are located at the upper section of the watershed, the section that harbors most remnants of native forest patches (UNISINOS, 2011; COMITESINOS, 2014). In
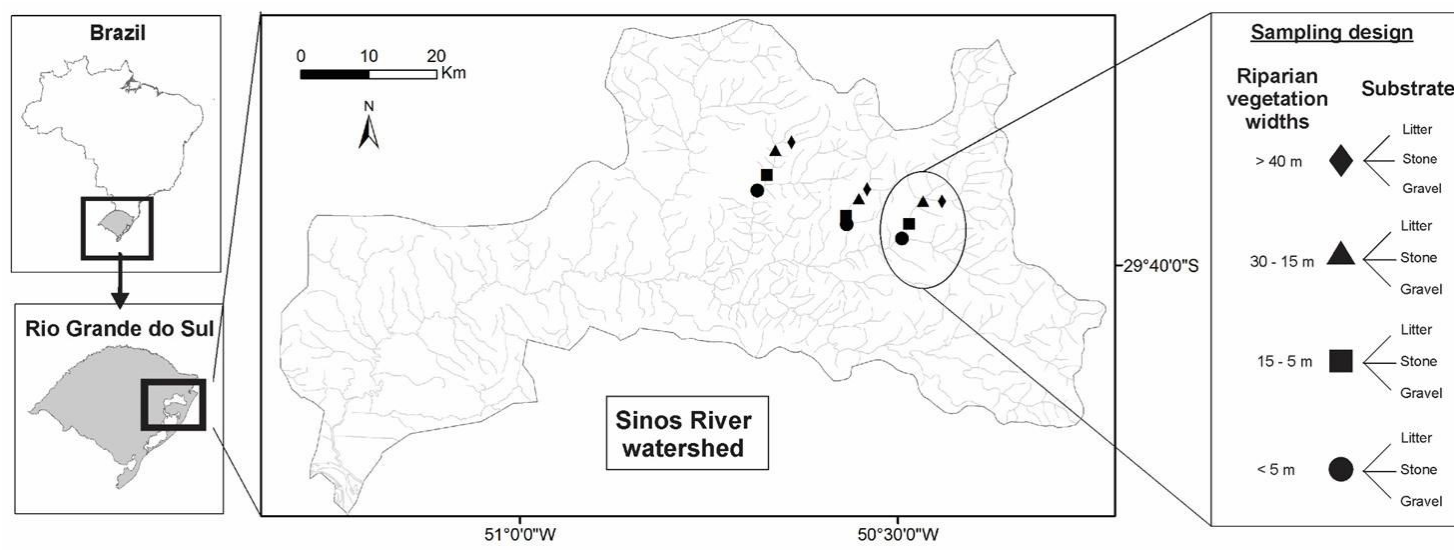

Figure 1. Sampling design and location of the study area. Adapted from: Viegas et al. (2014) and Braun et al. (2018). 
each tributary, the collections took place in four stream reaches differing in the width of the riparian vegetation. The minimum distance between reaches (within each tributary) was $1.2 \mathrm{~km}$. In addition, the variation in stream channel width was independent from the categories of riparian vegetation width associated with the longitudinal gradient covered in the study design (Moraes et al., 2014). Each reach was posteriorly classified into four categories of riparian widths. (i) '> $40 \mathrm{~m}$ ', i.e., reaches with vegetation widths wider than $40 \mathrm{~m}$ on both banks; (ii) '30-15 m', i.e., reaches with vegetation widths ranging from 15 to $30 \mathrm{~m}$ on both banks; (iii) ' $15-5 \mathrm{~m}$ ', i.e., reaches with vegetation widths ranging from 5 to $15 \mathrm{~m}$ on both banks; and (iv) ' $<5 \mathrm{~m}$ ', i.e., reaches with vegetation widths narrower than $5 \mathrm{~m}$ on both banks (Figure 1).

In the wider categories (over $>40$-m width), the riparian vegetation reached more than $1000 \mathrm{~m}$ in one of the banks, and ranged between 200 and $400 \mathrm{~m}$ in the other. In spite of the longitudinal gradient of riparian vegetation width (decreasing widths downstream), stream order and land use were similar among the three tributaries over the sampled gradient. In addition, previous botanic inventories in the study area showed that the composition of the riparian forest was similar across stream segments (Oliveira et al., 2013).

\subsection{Sampling procedures}

Samplings occurred in the austral winter of 2010 (August) and in the summer of 2011 (January), in days of no rainfall. A Surber sampler (dimensions: $30 \times 30 \mathrm{~cm} ; 250-\mu \mathrm{m}$ mesh size) was used for collecting the larvae in stone (grain size: $20-28 \mathrm{~cm}$ ) and gravel (grain size: $1-6.5 \mathrm{~cm}$ ) substrates. A hand net ( $30 \mathrm{~cm}$ in diameter; $250-\mu \mathrm{m}$ mesh size) was used to collect the larvae in leaf litter substrate in the stream bank and pool microhabitats. Six subsamples were taken per substrate type and posteriorly pooled into a single sampling unit. Dissolved oxygen, electrical conductivity, $\mathrm{pH}$, turbidity and water temperature were measured in situ in each stream reach with a multiparameter probe.

In the laboratory, individuals were sieved and collected under stereomicroscope. Larvae were posteriorly determined to genus level whenever possible after consultation to specialized literature (Costa et al., 2004). Individuals were stored in 80\% alcohol and archived in the Aquatic Insect collection of the Laboratory of Ecology and Conservation of Aquatic Ecosystems of UNISINOS (São Leopoldo, Rio Grande do Sul, Brazil).

\subsection{Data analysis}

Because of the seasonal sampling design of the study (winter and summer samplings) and prior evidence of seasonal dynamics in odonate communities in southern Brazil (Pires et al., 2014, 2019, 2020), we first assessed whether Odonata community composition changed between seasons before proceeding to the main analyses. For this purpose, we carried out a non-parametric multivariate analysis of variance (PERMANOVA; 9999 permutations) with the raw dataset $(\mathrm{N}=72$; three tributaries $\mathrm{x}$ four reaches $\mathrm{x}$ three substrate $\mathrm{x}$ two seasons). We carried out the tests using incidence-based composition datasets. The distance matrix used was based on the Sørensen dissimilarity index. The PERMANOVA did not detect significant difference in odonate composition between seasons $\left(\mathrm{R}^{2}=0.02 ;\right.$ Pseudo-F $\left.=1.12 ; P=0.31\right)$. In the following procedures, we thus used a matrix with the pooled the composition of the two seasons (36 rows representing the sampling units) as the response dataset.

In order to check whether the set of water physicochemical variables changed among the riparian vegetation widths, we conducted a multivariate analysis of variance (MANOVA). In this step, variables not normally distributed were $\log$ transformed to meet this assumption, and in accordance to the sampling design of the study, we repeated this procedure for each subset of seasons (winter and summer subsets). The MANOVA detected no difference in the set of water physicochemical variables measured among riparian vegetation widths in both sampling periods (summer: Pillai's trace $=1.63 ; P=0.51$; winter: Pillai's trace $=1.64 ; P=0.49)$. Therefore, we did not include the influence of other water-level and habitat structure environmental variables in our assessment. In relation to the land use in the study region, previous data indicated that the land-use classes (agriculture, pasture and urban areas) did not change among riparian vegetation widths, except for forest area, which were larger in the wider buffers (i.e., widths higher than $40 \mathrm{~m}$ ). The original information on the land use in the study area is available in Moraes et al. (2014) and Braun et al. (2018).

\subsection{Assessment of the influence of substrate types and riparian vegetation widths}

We visually assessed the variation in Odonata composition among riparian vegetation widths and substrate types through ordination diagrams based on 
principal coordinates analysis (PCoA). For statistical validation, we ran a two-way PERMANOVA with interaction (riparian vegetation widths and substrate types as main effects; 9999 permutations) using the tributary identity as blocking factor. A previous study on the community structure of aquatic macroinvertebrates conducted in the same watershed suggested that riparian buffer widths narrower than $15 \mathrm{~m}$ altered the macroinvertebrate community structure (Moraes et al., 2014). We thus further conducted a second assessment to test whether Odonata community structure patterns also varied with the abovementioned 'threshold'. The original categories of riparian vegetation widths were reclassified according to the following levels of resolution, which took into account the 15 m-width as breakpoint: 'narrower' (which lumped the original ' $<5 \mathrm{~m}$ ' and ' $15-5 \mathrm{~m}$ ' categories); and 'broader' (which lumped the original '> $40 \mathrm{~m}$ ' and ' $30-15 \mathrm{~m}$ ' categories). We hereafter refer to each level of resolution as 'fine' (four categories of vegetation widths) and 'coarse' (two categories of vegetation widths) (Figure 2). All analyses were carried out using the $\mathrm{R}$ program ( $\mathrm{R}$ Core Team, 2019). We used the following functions from the vegan package: adonis for PERMANOVA and cmdscale for PCoA (Oksanen et al., 2019).

\section{Results}

\subsection{Community structure of Odonata}

We collected 408 individuals from six families and 19 taxa of Odonata (16 genera and three additional unidentified taxa) over the sampling period. These included 178 individuals of Anisoptera (15 taxa from three families, including 13 genera and two unidentified taxa) and 230 individuals of Zygoptera (four taxa from three families: three genera and an additional taxa identified to family level). Libellulidae and Gomphidae were the richest families (eight and five taxa, respectively). Coenagrionidae was the dominant family (45.3\%). Argia Rambur, 1842 (Coenagrionidae) was the dominant genus, followed by Progomphus Selys, 1854 (Gomphidae), comprising 39.5\% and 25.2\% of the individuals collected, respectively. Eight taxa occurred exclusively in a single riparian width. The total number of individuals collected was similar across substrate types (Table 1).

At the fine level (four categories of vegetation widths), the PERMANOVA detected a significant influence of substrate type and of the interaction between substrate type and riparian vegetation widths on odonate composition $(P<0.05)$. At the coarse level (two categories of vegetation widths),

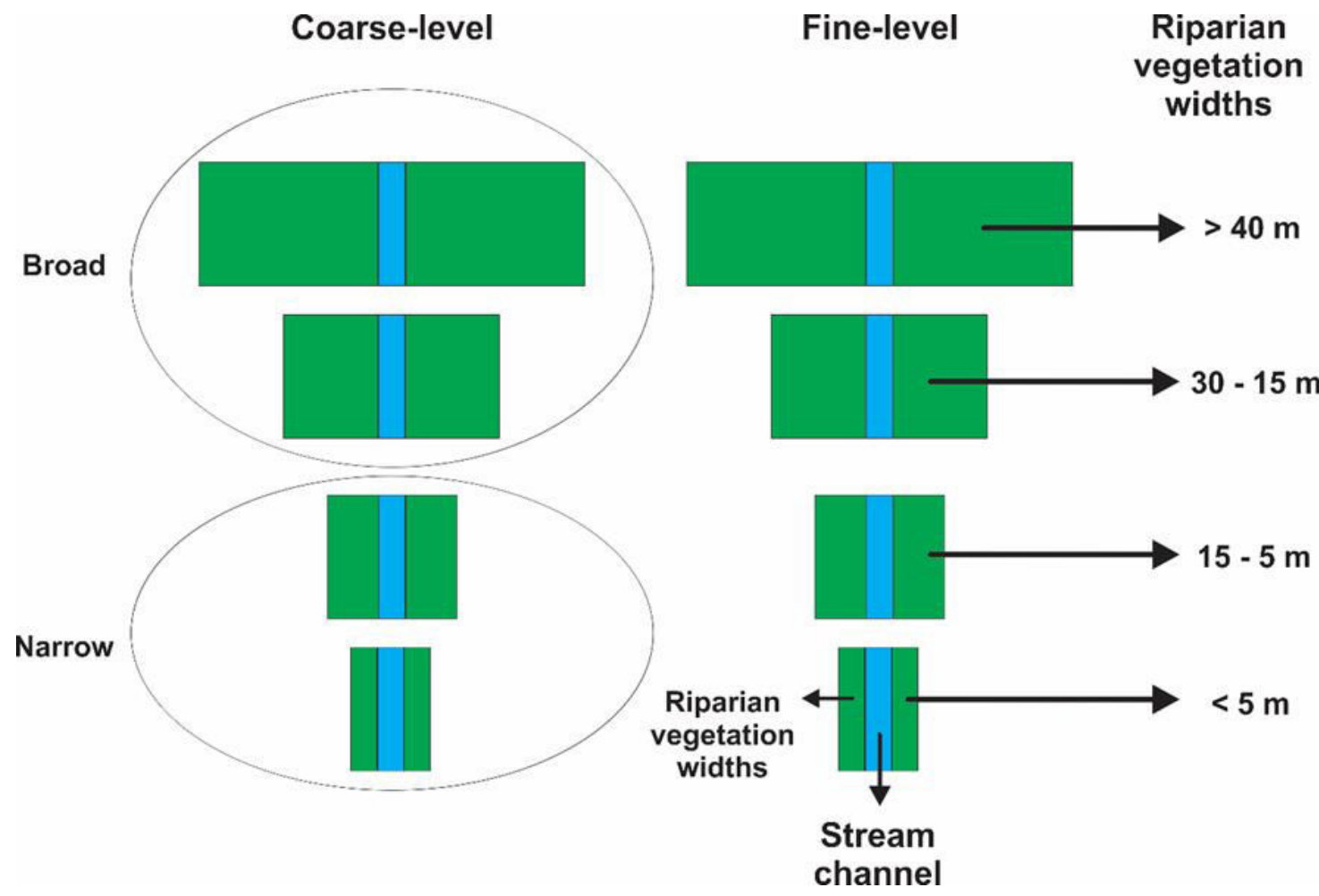

Figure 2. Schematic representation of the two levels of resolution (coarse and fine) adopted for the assessment of the effects of riparian vegetation widths in this study. 
the PERMANOVA detected a significant effect of riparian vegetation widths, substrate type and of the interaction between substrate type $(P<0.05)$ on community composition (Table 2 ).

Little segregation was observed in odonate composition among the finer-scale riparian vegetation widths (Figure 3A), whereas odonate composition varied more clearly between the coarser categories of riparian vegetation widths (Figure 3B). Nevertheless, the most evident segregation was detected among substrate types. The composition in litter substrates strongly differed from stone and gravel substrates (Figure 4A). Argia, Brechmohoga Kirby, 1894 (Libellulidae) and Progomphus were more associated with stone and gravel substrates, while Calopterygidae, Oxystigma

Table 1. Relative and total abundance, composition and richness of larval odonates recorded in stream reaches with different riparian vegetation widths and substrate types in Southern Brazil.

\begin{tabular}{|c|c|c|c|c|c|c|c|c|}
\hline & \multicolumn{4}{|c|}{ Riparian vegetation width (m) } & \multicolumn{3}{|c|}{ Substrate type } & \multirow{2}{*}{ Total } \\
\hline & $>40$ & $30-15$ & $15-5$ & $<5 \mathrm{~m}$ & $\mathrm{~L}$ & $\mathbf{s}$ & G & \\
\hline \multicolumn{9}{|l|}{ Anisoptera } \\
\hline \multicolumn{9}{|l|}{ Aeshnidae } \\
\hline Limnetron Förster, 1907 & 0.01 & & & & 0.01 & & & 1 \\
\hline Aeshnidae gen. 1 & & 0.01 & & & 0.01 & & & 1 \\
\hline \multicolumn{9}{|l|}{ Gomphidae } \\
\hline Cacoides Cowley, 1934 & & & & 0.05 & 0.03 & & & 4 \\
\hline Phyllocycla Calvert, 1948 & & & 0.03 & 0.02 & 0.04 & & & 6 \\
\hline Phyllogomphoides Belle, 1970 & 0.06 & 0.03 & 0.01 & 0.01 & 0.07 & 0.01 & & 11 \\
\hline Progomphus Selys, 1854 & 0.23 & 0.21 & 0.34 & 0.20 & 0.05 & 0.38 & 0.32 & 103 \\
\hline Tibiogomphus Selys, 1854 & & 0.02 & 0.05 & 0.12 & 0.12 & & 0.02 & 18 \\
\hline \multicolumn{9}{|l|}{ Libellulidae } \\
\hline Brechmohoga Kirby, 1894 & & 0.01 & & & 0.01 & & & 1 \\
\hline Elasmothemis Westfall, 1988 & 0.02 & & 0.04 & 0.06 & & 0.06 & 0.02 & 12 \\
\hline Elga Ris, 1911 & & & 0.02 & & 0.01 & & & 2 \\
\hline Gynothemis Calvert \& Ris, 1909 & 0.02 & 0.03 & 0.01 & 0.01 & 0.04 & & 0.01 & 7 \\
\hline Idiataphe Cowley, 1934 & & 0.02 & & & 0.01 & & & 2 \\
\hline Macrothemis Hagen, 1868 & 0.02 & 0.03 & 0.01 & 0.01 & 0.04 & 0.01 & 0.0 & 7 \\
\hline Planiplax Muttkowski, 1910 & & 0.02 & & & 0.01 & & & 2 \\
\hline Libellulidae gen. 1 & & 0.01 & & & 0.01 & & & 1 \\
\hline \multicolumn{9}{|l|}{ Zygoptera } \\
\hline Calopterygidae & 0.08 & 0.08 & 0.04 & 0.16 & 0.24 & 0.01 & 0.02 & 35 \\
\hline \multicolumn{9}{|l|}{ Coenagrionidae } \\
\hline Argia Rambur, 1842 & 0.32 & 0.44 & 0.45 & 0.35 & 0.05 & 0.52 & 0.61 & 161 \\
\hline Telebasis Selys, 1865 & 0.20 & 0.05 & & & 0.18 & & & 24 \\
\hline \multicolumn{9}{|l|}{ Heteragrionidae } \\
\hline Oxystigma Selys, 1854 & 0.03 & 0.05 & 0.02 & & 0.04 & 0.01 & 0.02 & 10 \\
\hline Abundance & 95 & 107 & 125 & 81 & 134 & 144 & 130 & \\
\hline Richness & 10 & 14 & 11 & 10 & 18 & 7 & 7 & \\
\hline
\end{tabular}

Abbreviations: $\mathrm{L}=$ litter; $\mathrm{S}=$ stone; $\mathrm{G}=$ gravel.

Table 2. Summary of the PERMANOVAs for the effects of the riparian vegetation widths and substrate types on the composition of larval odonates in the study area.

\begin{tabular}{clccc}
\hline Resolution & \multicolumn{1}{c}{ Predictor } & pseudo-F & $\mathbf{R}^{2}$ & $\mathbf{P}$ \\
\hline Fine-level & Riparian width & 1.063 & 0.051 & 0.3860 \\
& Substrate & $\mathbf{1 3 . 3 1 9}$ & $\mathbf{0 . 4 2 1}$ & $\mathbf{0 . 0 0 0 1}$ \\
& Riparian width *substrate & $\mathbf{1 . 8 3 9}$ & $\mathbf{0 . 1 7 4}$ & $\mathbf{0 . 0 4 9 4}$ \\
& Tributary & 0.773 & 0.024 & 0.5850 \\
Coarse-level & Riparian width & $\mathbf{2 . 9 1}$ & $\mathbf{0 . 0 4 3}$ & $\mathbf{0 . 0 4 5 0}$ \\
& Substrate & $\mathbf{1 3 . 9 8 1}$ & $\mathbf{0 . 4 2 1}$ & $\mathbf{0 . 0 0 0 1}$ \\
& Riparian width *substrate & $\mathbf{1 . 1 1 2}$ & $\mathbf{0 . 1 0 2}$ & $\mathbf{0 . 0 0 7 0}$ \\
& Tributary & 0.877 & 0.026 & 0.5140 \\
\hline
\end{tabular}

Bold values indicate significant effects $(\mathrm{P}<0.05)$. For the details on criteria for each level of resolution, see the definitions in subsection 2.4 in Material and Methods. ${ }^{*}=$ symbol representing interaction term between factors. 


\section{(A) Riparian widths}

\section{Fine level}

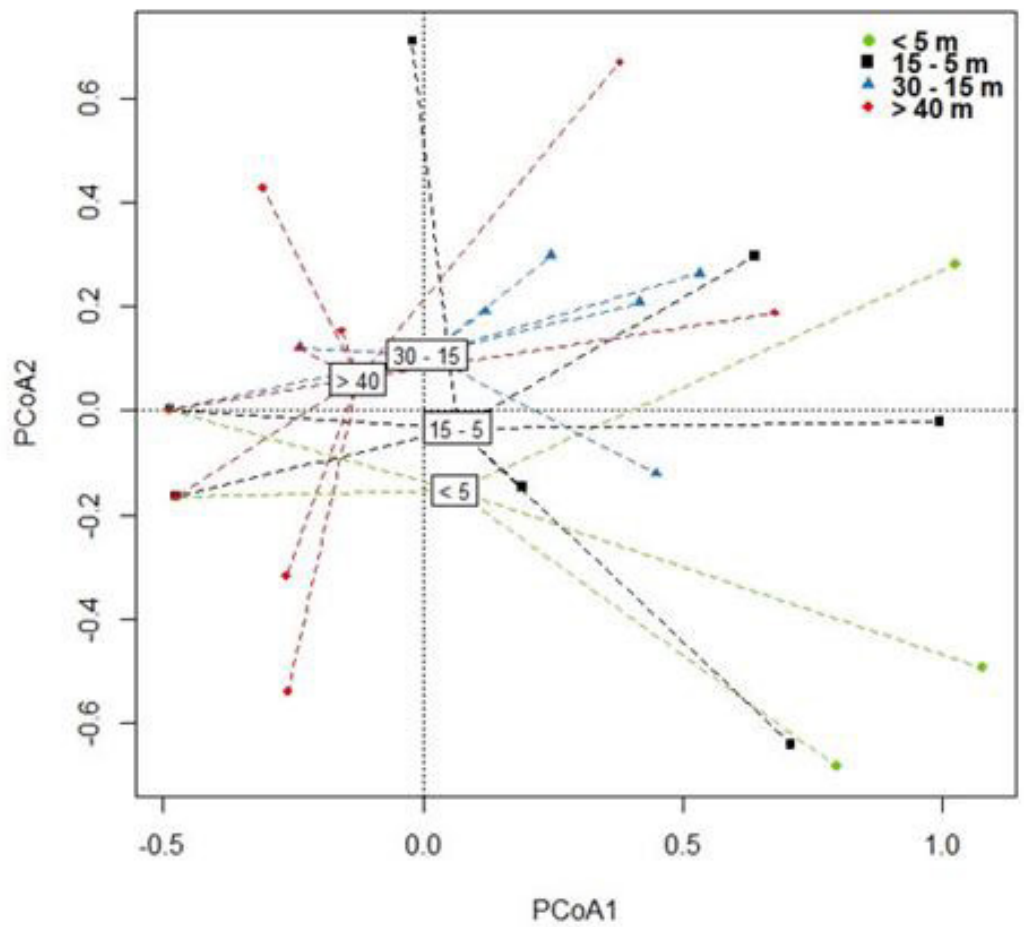

(B) Riparian widths

Coarse level (threshold $=15 \mathrm{~m}$ )

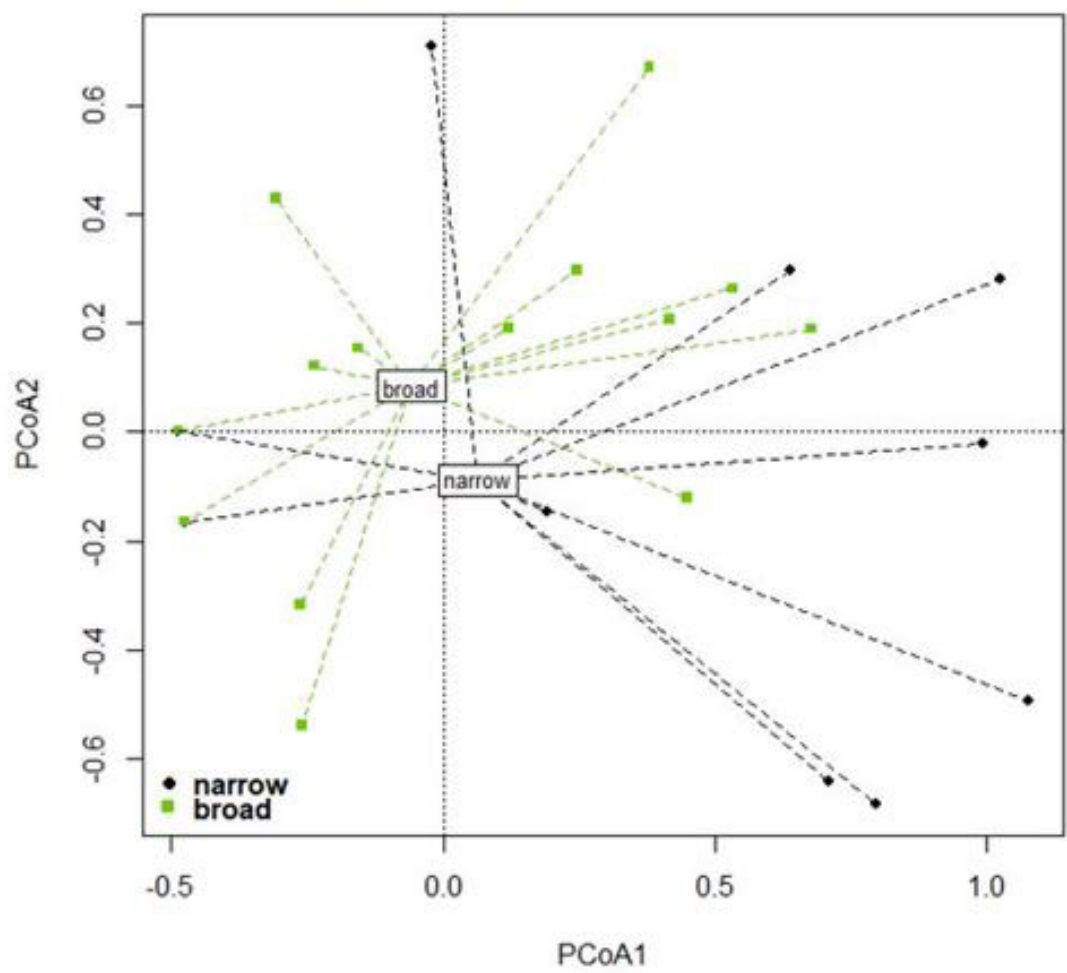

Figure 3. PCoA ordination diagrams of the composition of the larval communities of Odonata according to riparian vegetation width (A: fine resolution (two classes of riparian vegetation width); B: coarse resolution (two classes of riparian vegetation width)). 


\section{(A) Substrate type}

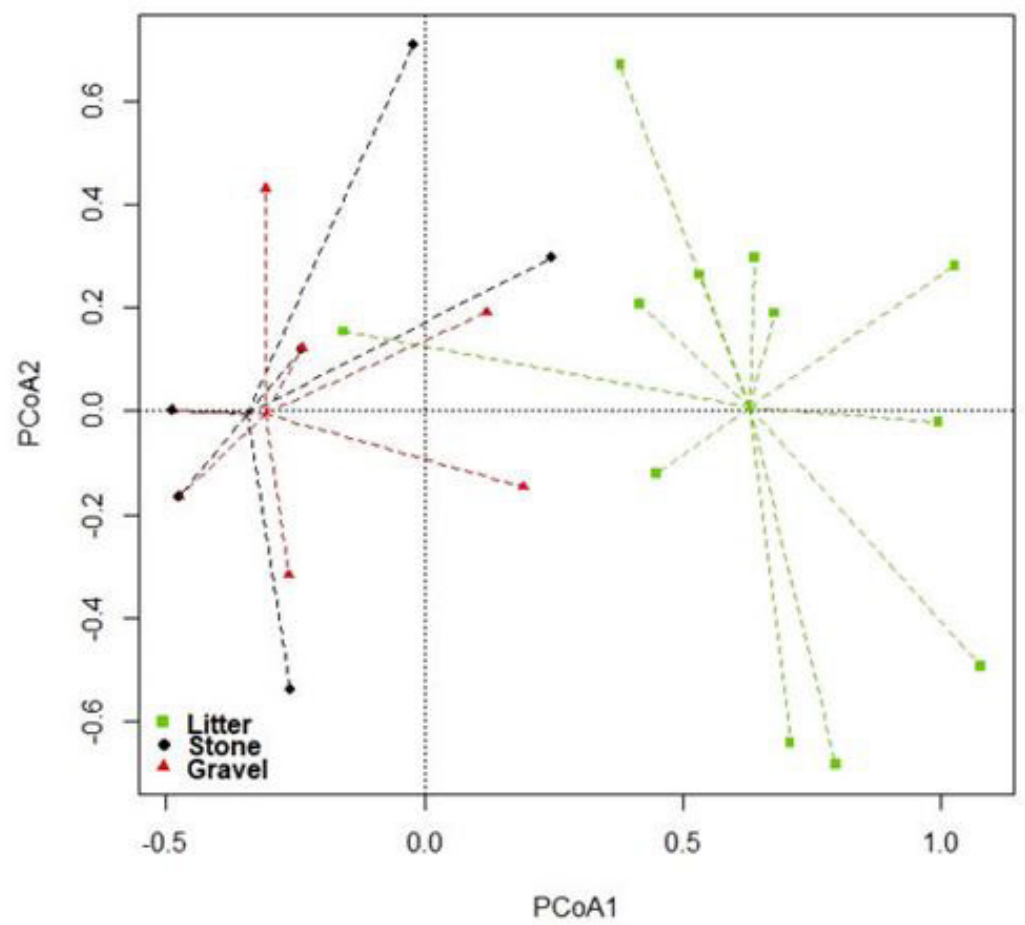

(B) Composition

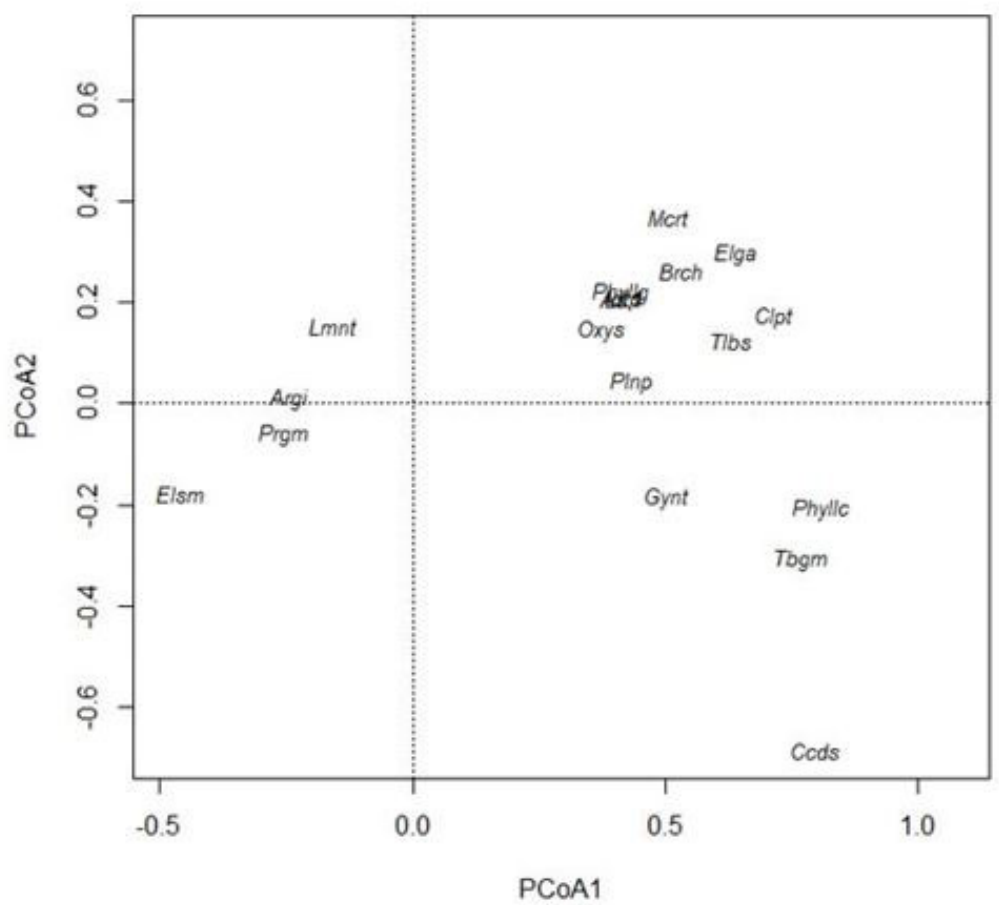

Figure 4. PCoA ordination diagrams of the composition of the larval communities of Odonata according to (A) substrate types; (B) Adjusted scores of the odonate taxa. Labels for Anisoptera taxa: Prgm = Progomphus; Phyllc = Phyllocycla; Tbgm = Tibiogomphus; Phyllg = Phyllogomphoides; Ccds = Cacoides (Gomphidae); Elsm: Elasmothemis; Plnp: Planiplax; Mcrt: Macrothemis; Elga = Elga; Gynt: Gynothemis; Idtp: Idiataphe; Brch: Brechmohoga; L..1: Libellulidae. gen.1 (Libellulidae); Lmnt: Limnetron; As.1: non-identified Aeshnidae (Aeshnidae); Labels for Zygoptera taxa: Clpt: Calopterygidae; Argi: Argia; Tlbs: Telebasis (Coenagrionidae); Oxys: Oxystigma (Heteragrionidae). 
Selys, 1854 (Heteragrionidae), Phyllocyla Calvert, 1948, Phyllogomphoides Belle, 1970 (Gomphidae), Gynothemis Calvert \& Ris, 1909 and Macrothemis Hagen, 1868 (Libellulidae) predominated in litter (Figure 4B).

\section{Discussion}

The composition of odonate larvae varied among substrate types and reaches with different riparian vegetation widths in subtropical Atlantic Forest streams in southern Brazil. Many authors showed that Odonata composition is affected by changes in the structure and integrity of the riparian vegetation in tropical regions from Brazil (Amazon and Cerrado biomes; Carvalho et al., 2013; Juen et al., 2014; Dutra \& De Marco Júnior, 2015; Calvão et al., 2018; Mendes et al., 2019, 2020). However, most of the aforementioned studies assess the effects of the conversion of riparian vegetation to anthropic land uses rather than variation in riparian vegetation widths (i.e., broadly corresponding to the amount of forest cover). The effects of reductions in the riparian vegetation width on stream insect communities and particularly on Odonata remain, in general, largely unknown in subtropical regions of Brazil, where fewer studies have been carried out (Siegloch et al., 2017). In this sense, recent studies showed that changes in the amount of forest cover affect the composition of odonates, as detected by Rodrigues et al. $(2016,2019)$ and ValenteNeto et al. (2016) in streams running through the transition between semi-deciduous and savanna landscapes. Our results are roughly in line with those three studies, as the composition of odonate larvae varied according to reductions in riparian vegetation width, and broadly supported our main hypothesis.

In relation to the relationship between odonate distribution and forest cover, Rodrigues et al. (2016) described that most of the indicator species of Odonata had negative relationships with loss of forest cover. Although this study was conducted along a shorter extent, our results roughly resemble the findings by Rodrigues et al. (2016) on the relationships of Odonata communities and amount of forest cover. In this study, $-42 \%$ of the pool of odonate taxa (eight out of 19) exclusively occurred in each one of the categories of riparian vegetation width. This result suggests that different odonate taxa abruptly responded to reduction in riparian vegetation width in the study area. More specifically, this value adds up to ten out of 19 (> 50\%) considering the two major categories (narrower and broader than $15 \mathrm{~m}$ ). More specifically, the majority of taxa was exclusive of the narrower widths $(<15 \mathrm{~m}$ : three out of $19 ; 15 \%)$, while seven out of 19 ; (35\%) occurred exclusively in the broader widths (> $15 \mathrm{~m}$ ). Our findings suggest that few odonate species specialize in reaches with extreme reduced riparian vegetation (assumedly more degraded), whereas a larger part of the pool was restricted to reaches with wider riparian vegetation. In addition, our results corroborated the findings of Moraes et al. (2014) on the importance of riparian widths wider than $15 \mathrm{~m}$ in sustaining less altered communities of stream insects. In this context, this result provides initial evidence for the potential effectiveness of odonates in detecting impacts at the riparian scale in subtropical Atlantic Forest streams.

As for the expectation on the differential distribution of Anisoptera and Zygoptera, we observed a general distinction between the compositions of each suborder across categories of riparian vegetation widths. Most taxa from Anisoptera (Gomphidae and Libellulidae families) either thrived or were exclusive of widths narrower than 15 m. In turn, for Zygoptera, Argia (the most frequent taxa of this suborder) was more associated with wider widths (Figure 4B). In addition, 50\% of the Zygoptera taxa recorded in this study were absent from the narrowest width (less than $5 \mathrm{~m}$ ) (Table 1). Changes in the structure of the riparian vegetation can influence odonate composition through reductions of available habitats for adult dispersal and survival (Petersen et al., 2004). Riparian vegetation also helps regulate the activity patterns of odonates (e.g., foraging, reproduction and oviposition), which depend on sunlight and temperature regimes (Corbet, 2004; De Marco Júnior \& Resende, 2004; Corbet \& May, 2008). These abiotic regimes vary with the riparian vegetation cover (Moore et al., 2005). Thus, increasing reductions in riparian vegetation should represent a significant thermoregulatory constraint for the occurrence of certain odonate species, and eventually affect the community composition (De Marco Júnior et al., 2015). Specifically, the odonates from the suborder Anisoptera (e.g., Gomphidae and Libellulidae) have larger body sizes and are more tolerant to warmer temperatures, and are expected to predominate in streams with lower integrity of riparian vegetation. Most Zygoptera taxa, in contrast, are smaller-bodied and thermal conformers, and thus less tolerant to warmer temperatures and increased sunlight exposure and less prone to thrive in riparian habitats with lower 
integrity (Ferreira-Peruquetti \& Fonseca-Gessner, 2002; Juen et al., 2014; De Marco Júnior et al., 2015; Calvão et al., 2018). Many authors evidenced that the distribution of each suborder is differently associated with riparian habitat loss, showing that adults from Anisoptera taxa usually thrive in altered, degraded riparian zones, while Zygoptera tend to be more associated with riparian habitats with higher integrity (Carvalho et al., 2013; OliveiraJúnior et al., 2015). Similar evidence for the abovementioned pattern also includes studies with larval stages (Mendes et al., 2019). Our results have generally supported this pattern, because Zygoptera taxa were more closely associated with the broader riparian vegetation widths, while Anisoptera comprised the predominant subset of taxa in the narrower widths. Thus, the observed pattern in this study suggests that the adults of Anisoptera were capable of tolerating the (assumedly) lower environmental integrity in reaches with reduced riparian vegetation widths, and corroborated our expectation.

However, the effects of different riparian vegetation widths on odonate composition depended on substrate type, i.e., the interaction between riparian vegetation width and substrate was important to explain odonate distribution. In addition, the effect of the interaction was significant in both levels of resolution (broad and fine). Here, odonate composition in organic substrates in streams with narrower riparian vegetation widths differed more clearly from inorganic substrates in reaches with wider riparian vegetation widths. The differences in life habit and behavior usually lead to specific association and preference by substrate types among larval odonate taxa (Corbet, 2004). In view of the low mobility of the larval stage, most odonate taxa tend to avoid microhabitats with stronger flow in lotic environments (Corbet, 2004; Suhling et al., 2015). Stream flow is generally higher in microhabitats characterized by coarser particles such as stone and gravel, while litter substrates are characterized by areas accumulation and deposition of organic material, with reduced water flow (Lampert \& Sommer, 2007; McCabe, 2011). However, allochthonous material input can vary with forest cover and thus impact the associated macroinvertebrates (Reid et al., 2008). Mendes et al. (2020) detected a relationship between changes in riparian vegetation structure and the community structure of odonate larvae, suggesting that reduction of native forest decreases the plant material in the stream compartment. In this study, although the amount of litter entering streams was not calculated across reaches, the narrower vegetation widths could have been associated with lower amount of litter. Such differential input could have likely limited the occurrence of larvae less adapted to coarser substrates and higher flow in reaches with narrower riparian vegetation, as previously discussed, and eventually lead to different composition across substrate types in reaches differing in the width of riparian vegetation. In specific, most of the predominant (or exclusive) taxa detected in litter substrates in (all Aeshnidae, most Gomphidae (except for Progomphus, see below), Coenagrionidae and Libellulidae) have larval stages with low mobility with life habits that favor establishment more suitable to areas of deposition such as litter (clinger or fossorial habit; as most Aeshnidae and Gomphidae; Carvalho \& Nessimian, 1998). In turn, Progomphus (which predominated in stone and gravel) larvae have burrowing habits that allow burial and establishment in coarser substrates (Carvalho \& Nessimian, 1998; Assis et al., 2004). The larvae of Argia show a range of life habits (sprawling and crawling), which likely explain their occurrence across substrates of different natures and higher flow (Assis et al., 2004). In fact, the predominance in stony substrates (e.g. stones and gravel) is in line with studies on the odonates in streams from subtropical Brazil (Carvalho \& Nessimian, 1998; Assis et al., 2004; Pires et al., 2020). Thus, the synergy between substrate type (organic: litter), differences in the input in litter amount and in water flow in each microhabitat likely converged for the effects of the interaction of substrate type with riparian widths in driving odonate composition.

\section{Conclusion}

This study detected significant shifts in the composition of odonate larvae among substrate types and reaches with different riparian vegetation widths in Southern Brazilian Atlantic Forest streams. In particular, the composition of odonate larvae in organic (litter) substrate in reaches with the narrower riparian vegetation widths strongly differed from inorganic (stones and gravel) substrates in reaches with the wider riparian vegetation widths. Our findings indicate that changes in forest cover at the riparian scale were differently associated with the distribution of odonate larvae at the instream compartment, and suggest that the effects of reductions in riparian vegetation on odonate distribution are not similar across substrate types. 
Our results are thus of interest for understanding the functioning and limnology of subtropical aquatic ecosystems in southern Brazil because they provide important evidence for the coupling of ecological processes operating at the riparian and in-stream compartments that drive insect distribution in subtropical forest streams.

\section{Acknowledgements}

This research was supported by funds from UNISINOS University (\#02.00.023/00-0) and PETROBRAS. CS and LM hold Research Productivity grants from the Brazilian National Council for Scientific and Technological Development (CNPq). MMP was granted a postdoctoral fellowship by $\mathrm{CNPq}$ (process \#151152/2018-7) and is currently supported by $\mathrm{CNPq}$ at UNISINOS Biology Graduate Program (process \#159829/2019-4).

\section{References}

ALLAN, J.D. and CASTILLO, M.M. Stream ecology: structure and function of running waters. Dordrecht: Springer, 2007. http://dx.doi.org/10.1007/978-14020-5583-6.

ASSIS, J.C.F., CARVALHO, A.L. and NESSIMIAN, J.L. Composição e preferência por microhábitat de imaturos de odonata (Insecta) em um trecho de baixada do Rio Ubatiba, Maricá-RJ, Brasil. Revista Brasileira de Entomologia, 2004, 48(2), 273-282. http://dx.doi.org/10.1590/S008556262004000200017

BRANCALION, P.H.S., GARCIA, L.C., LOYOLA, R., RODRIGUES, R.R., PILLAR, V.D. and LEWINSOHN, T.M. Análise crítica da Lei de Proteção da Vegetação Nativa (2012), que substituiu o antigo Código Florestal: atualizaçóes e ações em curso. Natureza \& Conservação, 2016, 14(1), 1-16. http://dx.doi.org/10.1016/j.ncon.2016.03.003.

BRASIL. Lei no 12.651, de 25 de maio de 2012. Código Florestal. Diário Oficial da União [da] República Federativa do Brasil, Poder Executivo, Brasília, DF, 28 maio 2012.

BRAUN, B.M., PIRES, M.M., STENERT, C., MALTCHIK, L. and KOTZIAN, C.B. Effects of riparian vegetation width and substrate type on riffle beetle community structure. Entomological Science, 2018, 21(1), 66-75. http://dx.doi.org/10.1111/ ens. 12283 .

BUSS, D.F., BAPTISTA, D.F., NESSIMIAN, J.L. and EGLER, M. Substrate specificity, environmental degradation and disturbance structuring macroinvertebrate assemblages in neotropical streams. Hydrobiologia, 2004,
518(1-3), 179-188. http://dx.doi.org/10.1023/ B:HYDR.0000025067.66126.1c.

CALVÃO, L.B., JUEN, L., OLIVEIRA-JÚNIOR, J.M., BATISTA, J.D. and MARCO JÚNIOR, P. Land use modifies Odonata diversity in streams of the Brazilian Cerrado. Journal of Insect Conservation, 2018, 22(5-6), 675-685. http://dx.doi.org/10.1007/ s10841-018-0093-5.

CARVALHO, A.L. and NESSIMIAN, J.L. Odonata do estado do Rio de Janeiro, Brasil: hábitats e hábitos das larvas. In: J.L. NESSIMIAN and A.L. CARVALHO, eds. Ecologia de insetos aquáticos. Rio de Janeiro: PPGE/UFRJ, 1998, pp. 3-28. http:// dx.doi.org/10.4257/oeco.1998.0501.01.

CARVALHO, F.G., PINTO, N.S., OLIVEIRAJÚNIOR, J.M. and JUEN, L. Effects of marginal vegetation removal on Odonata communities. Acta Limnologica Brasiliensia, 2013, 25(1), 10-18. http:// dx.doi.org/10.1590/S2179-975X2013005000013.

COMITÊ DE GERENCIAMENTO DA BACIA HIDROGRÁFICA DO RIO DOS SINOS COMITESINOS. Plano da bacia hidrográfica do Rio dos Sinos [online]. 2014 [viewed 11 Jan. 2016]. Available from: http://www.sema.rs.gov.br/upload/ Revista_Plano_Sinos.pdf

CORBET, P.S. and MAY, M.L. Fliers and perchers among Odonata: dichotomy or multidimensional continuum? A provisional reappraisal. International Journal of Odonatology, 2008, 11(2), 155-171. http:// dx.doi.org/10.1080/13887890.2008.9748320.

CORBET, P.S. Dragonflies: behaviour and ecology of Odonata. Colchester: Harley Books, 2004.

CORDEIRO, J.L.P. and HASENACK, H. Cobertura vegetal atual do Rio Grande do Sul. In: V.D.P. PILLAR, ed. Campos Sulinos: conservação e uso sustentável da biodiversidade. Brasília: Ministério do Meio Ambiente, 2009, pp. 285-299.

COSTA, J.M., SOUZA, L.O.I. and OLDRINI, B.B. Chave para as famílias e gêneros das larvas de Odonata citadas para o Brasil: comentários e registros bibliográficos. Publicaçōes Avulsas do Museu Nacional, 2004, 99, 1-43.

DALA-CORTE, R.B., MELO, A.S., SIQUEIRA, T., BINI, L.M., MARTINS, R.T., CUNICO, A.M., PES, A.M., MAGALHÁES, A.L.B., GODOY, B.S., LEAL, C.G., MONTEIRO-JÚNIOR, C.S., STENERT, C., CASTRO, D.M.P., MACEDO, D.R., LIMAJUNIOR, D.P., GUBIANI, É.A., MASSARIOL, F.C., TERESA, F.B., BECKER, F.G., SOUZA, F.N., VALENTE-NETO, F., SOUZA, F.L., SALLES, F.F., BREJÃO, G.L., BRITO, J.G., VITULE, J.R.S., SIMIÃO-FERREIRA, J., DIAS-SILVA, K., ALBUQUERQUE, L., JUEN, L., MALTCHIK, L., CASATTI, L., MONTAG, L., RODRIGUES, M.E., CALLISTO, M., NOGUEIRA, M.A.M., SANTOS, M.R., HAMADA, N., PAMPLIN, P.A.Z., POMPEU, P.S., LEITÃO, R.P., RUARO, R., 
MARIANO, R., COUCEIRO, S.R.M., ABILHOA, V., OLIVEIRA, V.C., SHIMANO, Y., MORETTO, Y., SÚAREZ, Y.R. and ROQUE, F.O. Thresholds of freshwater biodiversity in response to riparian vegetation loss in the Neotropical region. Journal of Applied Ecology, 2020, 57(7), 1391-1402. http:// dx.doi.org/10.1111/1365-2664.13657.

DE MARCO JÚNIOR, P. and RESENDE, D.C. Cues for territory choice in two tropical dragonflies. Neotropical Entomology, 2004, 33(4), 397-401. http:// dx.doi.org/10.1590/S1519-566X2004000400001.

DE MARCO JÚNIOR, P., BATISTA, J.D. and CABETTE, H.S.R. Community assembly of adult odonates in tropical streams: an ecophysiological hypothesis. PLoS One, 2015, 10(4), e0123023. http://dx.doi.org/10.1371/journal.pone.0123023. PMid:25906243.

DEATH, R.G. and COLLIER, K.J. Measuring stream macroinvertebrate responses to gradients of vegetation cover: when is enough enough? Freshwater Biology, 2010, 55(7), 1447-1464. http://dx.doi. org/10.1111/j.1365-2427.2009.02233.x.

DOSSKEY, M.G., VIDON, P., GURWICK, N.P., ALLAN, C.J., DUVAL, T.P. and LOWRANCE, R. The role of riparian vegetation in protecting and improving chemical water quality in streams. Journal of the American Water Resources Association, 2010, 46(2), 261-277. http://dx.doi.org/10.1111/j.17521688.2010.00419.x.

DUTRA, S. and DE MARCO JÚNIOR, P. Bionomic differences in odonates and their influence on the efficiency of indicator species of environmental quality. Ecological Indicators, 2015, 49, 132-142. http://dx.doi.org/10.1016/j.ecolind.2014.09.016.

FERREIRA-PERUQUETTI, P.S. and FONSECAGESSNER, A.A. Comunidade de Odonata (Insecta) em áreas naturais do cerrado e monocultura no nordeste do estado de São Paulo, Brasil: relação entre o uso do solo e a riqueza faunística. Revista Brasileira de Zoologia, 2002, 20(2), 219-224. http://dx.doi. org/10.1590/S0101-81752003000200008.

HEINO, J., MELO, A.S., SIQUEIRA, T., SOININEN, J., VALANKO, S. and BINI, L.M. Metacommunity organisation, spatial extent and dispersal in aquatic systems: patterns, processes and prospects. Freshwater Biology, 2015, 60(5), 845-869. http://dx.doi. org/10.1111/fwb.12533.

INIIGUEZ-ARMIJOS, C., LEIVA, A., FREDE, H.G., HAMPEL, H. and BREUER, L. Deforestation and benthic indicators: how much vegetation cover is needed to sustain healthy Andean streams? PLoS One, 2014, 9(8), e105869. http://dx.doi.org/10.1371/ journal.pone.0105869. PMid:25147941.

INSTITUTO BRASILEIRO DE GEOGRAFIA E ESTATÍSTICA - IBGE. Projeto RADAMBRASIL: levantamento de recursos naturais. Rio de Janeiro: IBGE, 1986.
INSTITUTO BRASILEIRO DE GEOGRAFIA E ESTATÍSTICA - IBGE. Manual técnico da vegetação brasileira. Rio de Janeiro: IBGE, 2012.

JUEN, L., OLIVEIRA-JUNIOR, J.M.B., SHIMANO, Y., MENDES, T.P. and CABETTE, H.S.R. Composição e riqueza de Odonata (Insecta) em riachos com diferentes níveis de conservação em um ecótone Cerrado-Floresta Amazônica. Acta Amazonica, 2014, 44(2), 223-233. http://dx.doi. org/10.1590/S0044-59672014000200008.

KIFFNEY, P.M., RICHARDSON, J.S. and BULL, J.P. Responses of periphyton and insects to experimental manipulation of riparian buffer width along forest streams. Journal of Applied Ecology, 2003, 40(6), 1060-1076. http://dx.doi.org/10.1111/j.13652664.2003.00855.x.

LAMPERT, W. and SOMMER, U. Special features of aquatic habitats. In: W. LAMPERT and U. SOMMER, eds. Limnoecology: the ecology of lakes and streams. New York: Oxford University Press, 2007. p. 12-32.

LEAL, C.G., BARLOW, J., GARDNER, T., HUGHES, R.M., LEITÃO, R.P., MAC NALLY, R., KAUFMANN, P.R., FERRAZ, S.F.B., ZUANON, J., DE PAULA, F.R., FERREIRA, J., THOMSON, J.R., LENNOX, G.D., DARY, E.P., RÖPKE, C.P. and POMPEU, P.S. Is environmental legislation conserving tropical stream faunas? A large-scale assessment of local, riparian and catchment-scale influences on Amazonian fish. Journal of Applied Ecology, 2018, 55(3), 1312-1326. http://dx.doi. org/10.1111/1365-2664.13028.

LIGEIRO, R., HUGHES, R.M., KAUFMANN, P.R., MACEDO, D.R., FIRMIANO, K.R., FERREIRA, W.R., OLIVEIRA, D., MELO, A.S. and CALLISTO, M. Defining quantitative stream disturbance gradients and the additive role of habitat variation to explain macroinvertebrate taxa richness. Ecological Indicators, 2013, 25, 45-57. http://dx.doi. org/10.1016/j.ecolind.2012.09.004.

LORION, C.M. and KENNEDY, B.P. Riparian forest buffers mitigate the effects of deforestation on fish assemblage in tropical headwater streams. Freshwater Biology, 2009, 19(2), 468-479. PMid:19323203.

LUKE, S.H., DOW, R.A., BUTLER, S., VUN KHEN, C., ALDRIDGE, D.C., FOSTER, W.A. and TURNER, E.C. The impacts of habitat disturbance on adult and larval dragonflies (Odonata) in rainforest streams in Sabah, Malaysian Borneo. Freshwater Biology, 2017, 62(3), 491-506. http:// dx.doi.org/10.1111/fwb.12880.

MARCZAK, L.B., SAKAMAKI, T., TURVEY, S.L., DEGUISE, I., WOOD, S.L.R. and RICHARDSON, J.S. Are forested buffers an effective conservation strategy for riparian fauna? Ecological Applications, 2010, 20(1), 126-134. http://dx.doi.org/10.1890/082064.1. PMid:20349835. 
MCCABE, D.J. Rivers and streams: life in flowing water. Nature Education Knowledge, 2011, 3, 19.

MENDES, T.P., AMADO, L.L., RIBEIRO, R.A.B. and JUEN, L. Morphological diversity of Odonata larvae (Insecta) and abiotic variables in oil palm plantation areas in the Eastern Amazon. Hydrobiologia, 2020, 847(1), 161-175. http://dx.doi.org/10.1007/s10750019-04079-y.

MENDES, T.P., BENONE, N.L. and JUEN, L. To what extent can oil palm plantations in the Amazon support assemblages of Odonata larvae? Insect Conservation and Diversity, 2019, 12(5), 448-458. http://dx.doi.org/10.1111/icad.12357.

MENDES, T.P., OLIVEIRA-JÚNIOR, J.M., CABETTE, H.S.R., BATISTA, J.D. and JUEN, L. Congruence and the biomonitoring of aquatic ecosystems: are odonate larvae or adults the most effective for the evaluation of impacts. Neotropical Entomology, 2017, 47(1), 37-45. http://dx.doi.org/10.1007/s13744017-0506-2. PMid:28285400.

MERRITT, R.W., CUMMINS, K.W. and BERG, M.B. An introduction to the aquatic insects of North America. Dubuque: Kendall Hunt Publishers, 2008.

MONTEIRO-JÚNIOR, C.S., JUEN, L. and HAMADA, N. Analysis of urban impacts on aquatic habitats in the central Amazon: adult odonates as bioindicators of environmental quality. Ecological Indicators, 2015, 48, 303-331. http://dx.doi.org/10.1016/j. ecolind.2014.08.021.

MOORE, R.D., SPITTLEHOUSE, D.L. and STORY, A. Riparian microclimate and stream temperature response to forest harvesting: a review. Journal of the American Water Resources Association, 2005, 41(4), 813834. http://dx.doi.org/10.1111/j.1752-1688.2005. tb04465.x.

MORAES, A.B., WILHELM, A.E., BOELTER, T., STENERT, C., SCHULZ, U.H. and MALTCHIK, L. Reduced riparian zone width compromises aquatic macroinvertebrate communities in streams of southern Brazil. Environmental Monitoring and Assessment, 2014, 186(11), 7063-7074. http://dx.doi. org/10.1007/s10661-014-3911-6. PMid:25052327.

OKSANEN, J., BLANCHET, F.G., FRIENDLY, M., KINDT, R., LEGENDRE, P., MCGLINN, D., MINCHIN, P.R., O'HARA, R.B., SIMPSON, G.L., SOLYMOS, P., STEVENS, M.H.H., SZOECS, E. and WAGNER, H. vegan: Community Ecology Package. R package version 2.5-6 [online]. Vienna: R Foundation for Statistical Computing, 2019 [viewed 25 Mar. 2020]. Available from: https:/CRAN.Rproject.org/package $=$ vegan

OLIVEIRA, J.M., MOURA, R.G., COSTA, L.J., PINHEIRO, C.C., VIEIRA, M.L. and FAGUNDES, M.V. Conversão de ecossistemas (1985-2010) e impacto do desmatamento de florestas ciliares na diversidade de árvores e arbustos na Bacia Hidrográfica do Rio dos Sinos. In: U.H. SCHULZ, ed. Projeto Verdesinos: resultados das pesquisas cientificas. São Leopoldo: C5 News Press, 2013, pp. 56-61.

OLIVEIRA-JUNIOR, J.M.B., SHIMANO, Y., GARDNER, T.A., HUGHES, R.M., DE MARCO JÚNIOR, P. and JUEN, L. Neotropical dragonflies (Insecta: Odonata) as indicators of ecological condition of small streams in the eastern Amazon. Austral Ecology, 2015, 40(6), 733-744. http://dx.doi. org/10.1111/aec. 12242 .

PETERSEN, I., MASTERS, Z., HILDREW, A.G. and ORMEROD, S.J. Dispersal of adult aquatic insects in catchments of differing land use. Journal of Applied Ecology, 2004, 41(5), 934-950. http://dx.doi. org/10.1111/j.0021-8901.2004.00942.x.

PIRES, M.M., KOTZIAN, C.B. and SPIES, M.R. Diversity and spatiotemporal distribution of larval odonate assemblages in temperate neotropical farm ponds. Journal of Insect Science, 2014, 14(1), 275. http://dx.doi.org/10.1093/jisesa/ieu 137. PMid:25527585.

PIRES, M.M., KOTZIAN, C.B., SGANZERLA, C., PRASS, G., DALZOCHIO, M.S. and PÉRICO, E. Diversity of Odonata (Insecta) in Seasonal Deciduous Forest fragments in southern Brazil (state of Rio Grande do Sul), with a new record for the state and comments on the seasonal distribution of the species. Biota Neotropica, 2019, 19(4), e20190769. http:// dx.doi.org/10.1590/1676-0611-bn-2019-0769.

PIRES, M.M., SIEGLOCH, A.E., HERNÁNDEZ, M.I.M. and PETRUCIO, M.M. Environmental drivers and composition of assemblages of immature odonates (Insecta) in a subtropical island in southern Brazil. Acta Limnologica Brasiliensia, 2020, 32, e2. http://dx.doi.org/10.1590/s2179-975x8017.

R CORE TEAM. R: a language and environment for statistical computing [online]. Vienna: R Foundation for Statistical Computing, 2019. [viewed 25 Mar. 2020]. Available from: https:/www.R-project.org/

REID, D.J., LAKE, P.S., QUINN, G.P. and REICH, P. Association of reduced riparian vegetation cover in agricultural landscapes with coarse detritus dynamics in lowland streams. Marine and Freshwater Research, 2008, 59(11), 998-1014. http://dx.doi.org/10.1071/ MF08012.

RIOS, S.L. and BAILEY, L.C. Relationship between riparian vegetation and stream benthic communities at three spatial scales. Hydrobiologia, 2006, 553(1), 153-160. http://dx.doi.org/10.1007/s10750-0050868-z.

RODRIGUES, M.E., DE OLIVEIRA ROQUE, F., QUINTERO, J.M.O., CASTRO PENA, J.C., SOUSA, D.C. and DE MARCO JUNIOR, P. Nonlinear responses in damselfly community along a gradient of habitat loss in savanna landscape. Biological Conservation, 2016, 194, 113-120. http:// dx.doi.org/10.1016/j.biocon.2015.12.001. 
RODRIGUES, M.E., ROQUE, F.O., GUILLERMOFERREIRA, R., SAITO, V.S. and SAMWAYS, M.J. Egg-laying traits reflect shifts in dragonfly assemblages in response to different amount of tropical forest cover. Insect Conservation and Diversity, 2019, 12(3), 231-240. http://dx.doi.org/10.1111/ icad.12319.

ROY, A.H., ROSEMOND, A.D., LEIGH, D.S., PAUL, M.J. and WALLACE, J.B. Habitat-specific responses of stream insects to land cover disturbance: biological consequences and monitoring implications. Journal of the North American Benthological Society, 2003, 22(2), 292-307. http://dx.doi.org/10.2307/1467999.

SAMWAYS, M.J. and STEYTLER, N.S. Dragonfly (Odonata) distribution patterns in urban and forest landscapes, and recommendations for riparian management. Biological Conservation, 1996, 78(3), 279-288. http://dx.doi.org/10.1016/S00063207(96)00032-8.

SHILLA, J.D. and SHILLA, D.A. Effects of riparian vegetation and bottom substrate on macroinvertebrate communities at selected sites in the Otara Creek, New Zealand. Journal of Integrative Environmental Sciences, 2012, 9(3), 131-150. http://dx.doi.org/10.1080/19 43815X.2012.709868.

SIEGLOCH, A.E., SCHMITT, R., SPIES, M.R., PETRUCIO, M.M. and HERNÁNDEZ, M.I.M. Effects of small changes in riparian forest complexity on aquatic insect bioindicators in Brazilian subtropical streams. Marine and Freshwater Research, 2017, 68(3), 519-527. http://dx.doi.org/10.1071/MF15162.

SOARES-FILHO, B.S., RAJÃO, R., MACEDO, M., CARNEIRO, A., COSTA, W.L.S., COE, M., RODRIGUES, H.O. and ALENCAR, A. Cracking Brazil's forest code. Science, 2014, 344(6182), 363364. http://dx.doi.org/10.1126/science.1246663.

SUHLING, F., SAHLÉN, G., GORB, S., KALKMAN, V.J., DIJKSTRA, K.-D.B. and VAN TOL, J. Order Odonata. In: J.H. THORP and A.P. COVICH, eds. Thorp and Covich's freshwater invertebrates: ecology and general biology. Cambridge: Academic Press, 2015, pp. 893-932. vol. I. http://dx.doi.org/10.1016/B9780-12-385026-3.00035-8.

SWEENEY, B.W., BOTT, T.L., JACKSON, J.K., KAPLAN, L.A., NEWBOLD, J.D., STANDLEY, L.J., HESSION, W.C. and HORWITZ, R.J. Riparian deforestation, stream narrowing, and loss of stream ecosystem services. Proceedings of the National Academy of Sciences of the United States of America, 2004, 101(39), 14132-14137. http://dx.doi. org/10.1073/pnas.0405895101. PMid:15381768.

TIEGS, S.D., COSTELLO, D.M., ISKEN, M.W., WOODWARD, G., MCINTYRE, P.B., GESSNER, M.O., CHAUVET, E., GRIFFITHS, N.A., FLECKER, A.S., ACUÑA, V., ALBARIÑO, R., ALLEN, D.C., ALONSO, C., ANDINO, P., ARANGO, C., AROVIITA, J., BARBOSA, M.V.M.,
BARMUTA, L.A., BAXTER, C.V., BELL, T.D.C., BELLINGER, B., BOYERO, L., BROWN, L.E., BRUDER, A., BRUESEWITZ, D.A., BURDON, F.J., CALliSTO, M., CANHOTO, C., CAPPS, K.A., CASTILLO, M.M., CLAPCOTT, J., COLAS, F., COLÓN-GAUD, C., CORNUT, J., CRESPOPÉREZ, V., CROSS, W.F., CULP, J.M., DANGER, M., DANGLES, O., DE EYTO, E., DERRY, A.M., VILLANUEVA, V.D., DOUGLAS, M.M., ELOSEGI, A., ENCALADA, A.C., ENTREKIN, S., ESPINOSA, R., ETHAIYA, D., FERREIRA, V., FERRIOL, C., FLANAGAN, K.M., FLEITUCH, T., FOLLSTAD SHAH, J.J., FRAINER BARBOSA, A., FRIBERG, N., FROST, P.C., GARCIA, E.A., GARCÍA LAGO, L., GARCÍA SOTO, P.E., GHATE, S., GILING, D.P., GILMER, A., GONÇALVES JÚNIOR, J.F., GONZALES, R.K., GRAÇA, M.A.S., GRACE, M., GROSSART, H.P., GUÉROLD, F., GULIS, V., HEPP, L.U., HIGGINS, S., HISHI, T., HUDDART, J., HUDSON, J., IMBERGER, S., INIIGUEZ-ARMIJOS, C., IWATA, T., JANETSKI, D.J., JENNINGS, E., KIRKWOOD, A.E., KONING, A.A., KOSTEN, S., KUEHN, K.A., LAUDON, H., LEAVITT, P.R., LEMES DA SILVA, A.L., LEROUX, S.J., LEROY, C.J., LISI, P.J., MACKENZIE, R., MARCARELLI, A.M., MASESE, F.O., MCKIE, B.G., OLIVEIRA MEDEIROS, A., MEISSNER, K., MILIŠA, M., MISHRA, S., MIYAKE, Y., MOERKE, A., MOMBRIKOTB, S., MOONEY, R., MOULTON, T., MUOTKA, T., NEGISHI, J.N., NERESLIMA, V., NIEMINEN, M.L., NIMPTSCH, J., ONDRUCH, J., PAAVOLA, R., PARDO, I., PATRICK, C.J., PEETERS, E.T.H.M., POZO, J., PRINGLE, C., PRUSSIAN, A., QUENTA, E., QUESADA, A., REID, B., RICHARDSON, J.S., RIGOSI, A., RINCÓN, J., RÎŞNOVEANU, G., ROBINSON, C.T., RODRÍGUEZ-GALLEGO, L., ROYER, T.V., RUSAK, J.A., SANTAMANS, A.C., SELMECZY, G.B., SIMIYU, G., SKUJA, A., SMYKLA, J., SRIDHAR, K.R., SPONSELLER, R., STOLER, A., SWAN, C.M., SZLAG, D., TEIXEIRA-DE MELLO, F., TONKIN, J.D., UUSHEIMO, S., VEACH, A.M., VILBASTE, S., VOUGHT, L.B.M., WANG, C.P., WEBSTER, J.R., WILSON, P.B., WOELFL, S., XENOPOULOS, M.A., YATES, A.G., YOSHIMURA, C., YULE, C.M., ZHANG, Y.X. and ZWART, J.A. Global patterns and drivers of ecosystem functioning in rivers and riparian zones. Science Advances, 2019, 5(1), eaav0486. http://dx.doi.org/10.1126/sciadv. aav0486. PMid:30662951.

UNIVERSIDADE DO VALE DO RIO DOS SINOS UNISINOS. Plano Sinos: plano de gerenciamento da bacia hidrográfica do Rio dos Sinos: meta 5: atividade 5.3: sintese do Plano de Bacia [online]. Esteio: Consórcio Pró-Sinos, Comitesinos; 2011 [viewed 30 Mar. 2020]. Available from: http://www.prosinos. rs.gov.br 
VALENTE-NETO, F., ROQUE, F.O., RODRIGUES, M.E., JUEN, L. and SWAN, C. Toward a practical use of Neotropical odonates as bioindicators: testing congruence across taxonomic resolution and life stages. Ecological Indicators, 2016, 61, 952-959. http://dx.doi.org/10.1016/j.ecolind.2015.10.052.

VALLE, I.C., BUSS, D.F. and BAPTISTA, D.F. The influence of connectivity in forest patches, and riparian vegetation width on stream macroinvertebrate fauna. Brazilian Journal of Biology = Revista Brasileira de Biologia, 2013, 73(2), 231-238. http://dx.doi. org/10.1590/S1519-69842013000200002. PMid:23917549.

VIEGAS, G., STENERT, C., SCHULZ, U.H. and MALTCHIK, L. Dung beetle communities as biological indicators of riparian forest widths in southern Brazil. Ecological Indicators, 2014,
36, 703-710. http://dx.doi.org/10.1016/j. ecolind.2013.09.036.

WANG, L., LYONS, J., RASMUSSEN, P., SEELBACH, P., SIMON, T., WILEY, M., KANEHL, P., BAKER, E., NIEMELA, S. and STEWART, P.M. Watershed, reach, and riparian influences on stream fish assemblages in the Northern Lakes and Forest Ecoregion, USA. Canadian Journal of Fisheries and Aquatic Sciences, 2003, 60(5), 491-505. http://dx.doi. org/10.1139/f03-043.

Received: 29 March 2020 Accepted: 16 July 2020

Associate Editors: Fabiana Schneck, Luiz Ubiratan Hepp. 